\title{
BÚCSÚ MESTERÜNKTŐL
}

\author{
„Tudjuk mi rég, mily könnyü, \\ mit mondanak nehéznek \\ és mily nehéz a könnyü, \\ mit a medvék lenéznek" \\ (Kosztolányi Dezső: Esti Kornél éneke)
}

Hoványi Gábor egyetemi magántanár, tanszékvezető, a közgazdaságtudományok doktora 90. életévében elhunyt.

Hoványi Gábor 1990 óta állt szoros kapcsolatban a Pécsi Közgazdaságtudományi Karral. Előbb címzetes egyetemi docensként, majd 1996-os habilitációja után egyetemi magántanárként, közben 1990 és 2000 között tanszékvezetőként, 1996-2006-ig a kari Habilitációs Bizottság tagjaként szolgálta a Kart. Tevékenységét a Kar 1999-ben, a jelölt 70. születésnapja alkalmából rendezett tudományos emléküléssel és a Pro Facultate Oeconomiaedij odaítélésével ismerte el.

Hoványi Professzor Úr több évtizeden keresztül oktatóként is erősítette intézményünket. A Magyar Tudományos Akadémia Ipar- és Vállalatgazdasági Kutatóintézete és a pécsi Kar együttmüködése közös, akadémiai tanszék létrehozásában öltött testet 1988-ban. Az ily módon létrejött Ipargazdaságtan Tanszék müködése modellértéküvé vált az akadémiai intézetek és az egyetemek oktatási kapcsolatainak formalizációjában. A tanszék tevékenységében a súlypontok áthelyeződését Hoványi Professzor Úr azon felismerése jelentette, amely a vezetési tanácsadás egyetemi oktatása iránti igényeket jelenítette meg. A Tanácsadás Tanszék kezdeményezése jó támogatókra talált a Vezetési- Szervezési Tanszék oktatóiban, és így vált igazi sikertörténetté a Karon a Vezetési Tanácsadás Specializáció. A tanulmányaikat befejezett specializációs hallgatók tudása a munkaerőpiacon igen jól hasznosítható a mai napig. A specializáció oktatása mögött közremüködők, támogatók széles köre állt. A nemzetközi tanácsadó cégek képviselői mellett a tanácsadói szakma magyar partnerei is támogatták e képzést.

Hoványi Gábor évtizedes kutatási/oktatási tapasztalatai, egy termékeny életpálya eredményei és bölcsessége teszik megalapozottá mindenkori válaszait.

A hallgatók és az oktatók a Professzor Úr által megszerzett anyagi hozzájárulásokban „fürödtek” ebben az időben.

Az általa vizsgált témák száma sok és szerteágazó. Szakirodalmi munkásságának legfontosabb területeit mutatom be a következőkben.

A Professzor Úr 1976-tól publikált a Vezetéstudományban, közel 20 írása jelent meg e folyóiratban. Első cikkeit a polgári vezetési elméletekről és a gyakorlat kritikájáról éppen itt jelentette meg. A Vezetéstudomány 1977. 3. és 5. számában találkozunk az amerikai és az angliai vállalati problémák elemzésével, a legújabb angol-amerikai vezetési módszerek bemutatásával. A Professzor Úr - ha egy téma felkeltette érdeklődését - sok helyen megmérettette annak mondanivalóját, fejleszthetőségét. Későbbi cikkeit előadta konferencián, az adott téma más közelítésben megjelent a folyóiratokban (Vezetéstudomány, Marketing és Menedzsment, Ipargazdasági Szemle, Magyar Tudomány, Közgazdasági Szemle stb.), majd az általa önállóan kiadott könyvekben.

1982-ben jelent meg a KJK-nál a „Vezetési modellek” címü könyve. A könyvet Susánszky János lektorálta. A feltételek - követelmények - feladatok (FKF) modellben megfogalmazottak a mai napig hasznosak. „A vezetönek folyamatosan figyelnie kell a feltételek alakulását, s ezeket értelmeznie kell követelmény- és feladatrendszerében" (25. o.). Ábrái, táblázatai kifejezőek, sokatmondóak. Nincs kifejezetten általánosan érvényes vezetői személyiségtípus, ezért nem lehet a személyiségjegyeknek olyan összessége, amely megadja az ideális vezetöt. Az FKF modellben a vezető személyiségét négy szférában ragadja meg: 1. az alkat, 2. a motiváció, 3. az ismeret és készség, 4. a magatartás szférájában. A könyv az egyes modellek ábrázolásával, elemzésével, folyamatainak rendezésével a szakma kiváló művelőjévé tette a szerzőt. Arra hívja fel a figyelmet, hogy a modellek technikai kialakításának és müködésének elve érvényes a szocialista vállalat vezetésében is. Ez a megközelítés jellemző akkor is, amikor a vállalatok innovációs készségeit elemzi.

Empirikus kutatásait összegezve, felhívja a vállalatok vezetőinek figyelmét a vállalatuk és saját személyük ,önvizsgálatának" fontosságára. Megállapítja, adatokkal bizonyítja, hogy az innovációs készség és néhány vállalati eredményességi mutató szoros kapcsolatban áll.

A Professzor Úr szívesen tanulta és használta az esettanulmányokat. Esettanulmányai az azokhoz kapcsolódó kiegészítések, adatok, táblázatok és kérdések most is alaposságát, külföldi tapasztalatainak integrálását, kíváncsiságát, folyamatos tanulásvágyát mutatják. Vezetőképző programokon szerzett diplomát a Bradford és a Harvard University-n. 
A „Gondolatok a szervezet menedzseléséről” (1998) c. írása a nemzetközi MBA-képzésben használt tananyagok kreatív feldolgozása, interpretálása. Minden esettanulmánya továbbgondolásra ösztönzi az olvasót, irányítja abban, hogy miről tünődhet el az egyes esetek kapcsán. Az esetek kreatív menedzsmentmeditációk.

Az oktatás során mindenkor párosította a hasznosat az érdekessel. Ez a hitvallás jellemzi a „Sikerkovácsok: Képzelt riport egy nemzetközi menedzsertalálkozóról” (2004) címü könyvét. A könyvről Kornai Gábor írja: egyaránt szól menedzserekhez és munkatársaikhoz. Érdekes stílusban megírt szakkönyv, amely hozzásegíti az olvasót a vezetői feladatok hatékony megoldásához.

2001-ben jelent meg a „Globális kihívások - menedzsmentválaszok" címü könyve. Ebben a globalizáció lényeges kérdéseire mutatott rá és arra, hogy a globalizációs folyamatokban keresni kell a lehetőségeket és azokat kell saját hasznunkra fordítani, a kihívásokra jó választ adni. Egyetemi előadásain gyakran hallottuk tőle: „Ha válságba jutsz, ebből biztosan hasznot húz valaki - hát miért ne te legyél az?"

Szívesen fogjuk kezünkbe a Gazdálkodástani Doktori Program keretében készült könyvét is.

Hoványi Gábor karunkon végzett sokéves oktatási tapasztalatának és széles körü nemzetközi menedzsment- ismereteinek különleges és sikeres ötvözése a „Menedzsmentmeditációk" (2002) címü könyve. A menedzsment legkülönbözőbb problémáit érzékeltető játékos helyzetekkel és történetekkel ösztönzi az olvasót a meditálásra.

Itt is és az egyetemi oktatás másik nagyszerü „tankönyvében”, a „Menedzsment tanácsadás” (1997) címü írásában újra megjelennek a különböző vezetési modellek és folyamatábrák. A Menedzsment Tanácsadás (MACO) szak (specializáció) sok évig tanulta ebből a könyvből a szakmájához elengedhetetlenül fontos ismereteket.

Abban is segített bennünket, hogy további rangos könyvek szülessenek a tanszék és a szakma képviselöinek tollából. Tanár Úr megtanított minket különbséget tenni fontos és jelentéktelen dolgok között. Ö nem csak a halálos ágyán döbbent rá, hogy mit kell komolyan venni: tisztelte a szakmáját, az időt, a barátait, az egészséget.

Hoványi Gábor szakirodalmi munkássága sokszorosan gazdagabb és sokrétübb annál, mint amit a fenti megemlékezés érintett. Hosszú, munkával teli élet zárult le a halálával.

Tisztelt és Szeretett Professzor Úr! Mi még sokat beszélgetünk Veled, emlékedet örökké örizzük! Nyugodjál békében!
Pécs, 2019. június 14. (Dr. Farkas Ferencné) 